\title{
GEOTECHNICAL INVESTIGATION OF THE ROCK SLOPE STABILITY PROBLEMS OCCURRED AT THE FOUNDATIONS OF THE COASTAL BYZANTINE WALL OF KAVALA CITY, GREECE
}

\author{
Loupasakis C. ${ }^{1}$, Spanou N. ${ }^{2}$, Kanaris D. ${ }^{3}$, Exioglou D. ${ }^{4}$, Georgakopoulos A. ${ }^{5}$ \\ ${ }^{1}$ Institute of Geology and Mineral Exploration, Engineering Geology Department, Olympic Village, 13677, \\ Acharnae,Greece,cloupas@igme.gr \\ ${ }^{2}$ Institute of Geology and Mineral Exploration, Engineering Geology Department, Olympic Village, 13677, \\ Acharnae,Greece,spanou@igme.gr \\ ${ }^{3}$ Institute of Geology and Mineral Exploration, Engineering Geology Department, Olympic Village, 13677, \\ Acharnae, Greece, dkanaris@igme.gr \\ ${ }^{4}$ Institute of Geology and Mineral Exploration, East Macedonia-Thrace Regional Branch, Brokoumi 30 \\ 67100, Xanthi, Greece, dimitrisexioglou@yahoo.gr \\ ${ }^{5}$ Aristotle University of Thessaloniki, School of Geology, Department of Mineralogy- \\ Petrology-Economic Geology, Laboratory of Economic Geology, 54124, Thessaloniki, Greece, \\ ageorgak@geo.auth.gr
}

\begin{abstract}
The coastal Byzantine wall of Kavala is located at the Panagia peninsula and it is founded on the Simvolou granite. The granite rock mass appears to be fractured by joint sets with very high persistence $(>20 \mathrm{~m})$ and very wide spacing $(60 \mathrm{~cm}-2 \mathrm{~m})$, forming large rock blocks. Further more, the Panagia peninsula is intersected by numerous parallel normal faults, forming extended zones of intensively fractured rock mass. Along the coastline the granite appear to be eroded by the sea waves, forming small gulfs around the faults.

The Byzantine wall is founded along the edge of the fractured slopes forming the coast line of the peninsula, arising issues about the safety of the historical construction. The joint sets form numerous rock wedges with unfavourable orientation, many sections of the slopes are undercut by the wave erosion and in the majority of the fault zones the rock mass presents intensive fragmentation.

The above described condition of the rock mass was recorded in detail along the entire coast line and all unstable sections were located. A full set of support measures was proposed for all unfavourable sections aiming to the improvement of the geotechnical behaviour of the rock mass, constituting the foundation formation of the Byzantine wall.
\end{abstract}

Key words: Rock slope stability, rock wedges, Panagia coastal Byzantine wall, Kavala

\section{Introduction}

Castles were constructed for ages in morphologically isolated locations providing the necessary additional natural defence. These locations besides their defensive advantage they leave these constructions exposed to the destructive powers of the nature. Rock slope stability problems, earth 


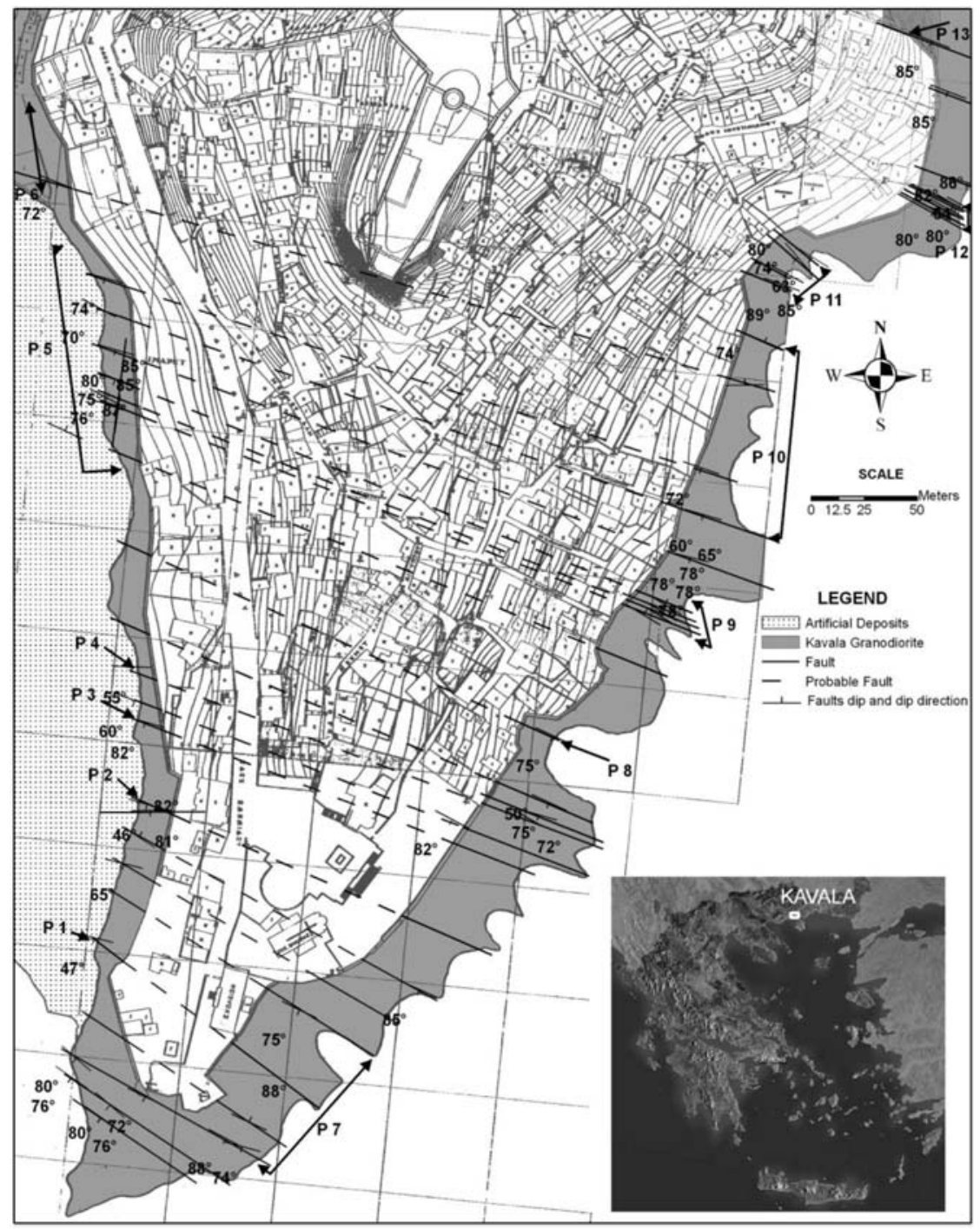

Fig. 1: Geological map of the peninsula presenting the location of the numerous normal faults recorded along the slopes. The gulfs excavated, by the wave erosion, along the faults` zones are clearly presented. The locations indicated by the P1 to P13 signs refer to parts where slope stability problems occur.

sliding problems, wave erosion, wind erosion are some of the most common phenomena damaging these historical monuments (Loupasakis \& Georgakopoulos, 2009; Topal et al., 2007; Greif, 2006; Donnelly et al, 2005; Kamh, 2005; Vlcko, 2004; Kolait \& Koumantakis, 1991; Ghosh, 1990).

Intense public interest for safeguarding such historical structures, requires the application of remedial measures. Several cases prove that these measures are usually focused on the preservation of the architectural character of the monuments, underestimating or overlooking the before mentioned geological - geotechnical problems. The destructions manifesting in some of these monuments prove that, comprehensive and detailed engineering geological and geotechnical investigations should be 
conducted before remedial and corrective measures are proposed and applied.

The coastal Byzantine wall of Kavala is a typical example of monument that, besides the controversial static sufficiency of the structure, several geotechnical issues arise concerning the stability of the rock slopes bearing the wall. The Byzantine wall of Kavala encloses Panagia's settlement which is sited at the homonymous triangular peninsula (Fig. 1). The settlement is located $60 \mathrm{~m}$ over the sea level and its boundaries are clearly distinguished by natural and artificial structures, such as the coastal wall, the slopes, the terrestrial wall and the byzantine aqueduct.

The main factor affecting the morphology of the peninsula and as a result the slope stability is the wave erosion. These erosive procedures combined with the tectonic fragmentation formed the vertical slopes bearing the wall. In several parts the slopes are intensively undercut, especially along the major tectonic faults intersecting the peninsula vertically (Fig. 1). The erosion along the coastline led to the formulation of repeated gulfs, reaching the base of the wall. Along the west side of the peninsula the erosive procedures are suspended because of the construction of an extended pier.

This paper is based on the results of an extended study conducted in Kavala, aiming to locate unstable slopes into the urban environment of the city and to propose measures for the improvement of the geotechnical behaviour of the rock mass. During the study the slopes surrounding the Panagia peninsula were analysed in details, providing substantial data for the condition of the rock mass and for its effect on the integrity of the overlay monument.

\section{Geological setting}

The wider study area is formed by Simvolou granite, part of the Rodopi plutonic mass. Simvolou granite is a big plutonic body sited to the SW part of Kavala prefecture, occupying an area of about $150 \mathrm{~km}^{2}$. The plutonic rock has been transformed under greenschist metamorphic phase. It is a granite - granodiorite, medium granuled and penetrated by a dense system of pegmatite and aplite veins. At places it shows a porphyritic texture with phenocrysts of K-feldspar (orthoclase) bigger than 5 centimeters. Two mineral phases can be noticed in the rock, one igneous and another metamorphic (IGME, 1973).

The main systems of faults of the Rodopic mass have SW - NE and NW - SE direction. Panagia peninsula is intersected by numerous parallel normal faults (Fig. 1), forming extended zones of intensively fractured rock mass. The sub-horizontal shearing, the dense systems of joints and the perpendicular faults intersect the rock mass forming numerous wedges along the slopes of the peninsula.

\section{Rock slope stability problems}

The stability of the rock slopes surrounding Panagia peninsula was examined taking under consideration the joint sets and the faults intersecting the rock mass, the morphology and the orientation of the slopes as well as the wave erosion effect and the location of the wall in relation to the slopes. Based on these data the slopes were divided in two major categories a) the slopes along the west southwest part of the peninsula, protected from the wave erosion by the pier and $b$ ) the slopes along the southeast part exposed to the sea action.

The western - south western slopes present dip ranging between $45^{\circ}$ and $90^{\circ}$ and height extending 10 to $20 \mathrm{~m}$ over the pier level. The Byzantine wall along several sections was founded close to the edge of the slopes and as a result slope failures can effect directly the integrity of the monument (Figs $2 \& 4)$. The stability problems are more intensive along the faults. The rock mass is fractured and 


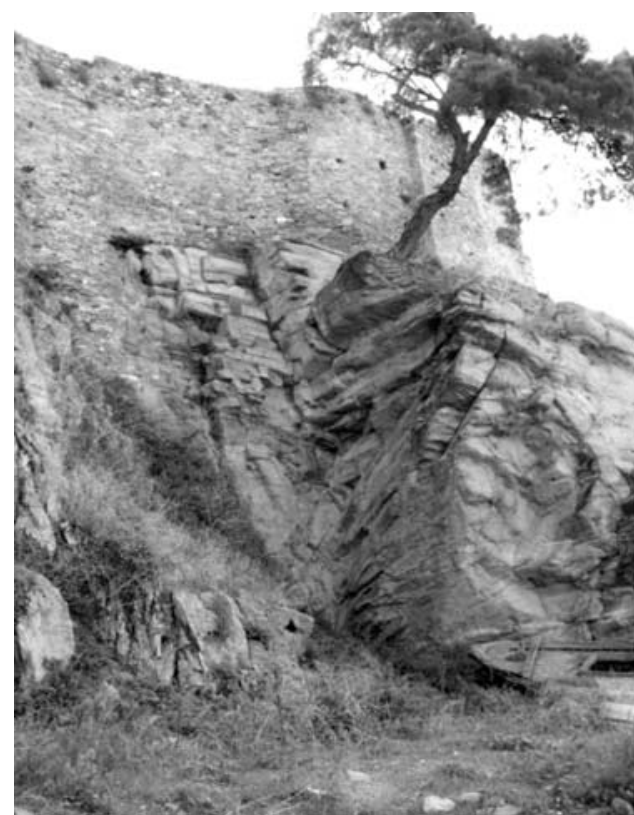

Fig. 2: Location P1. A fault intersects the slope forming a huge rock wedge and a wide fractured zone. The Wall fills the gap between the two sections of the fault.

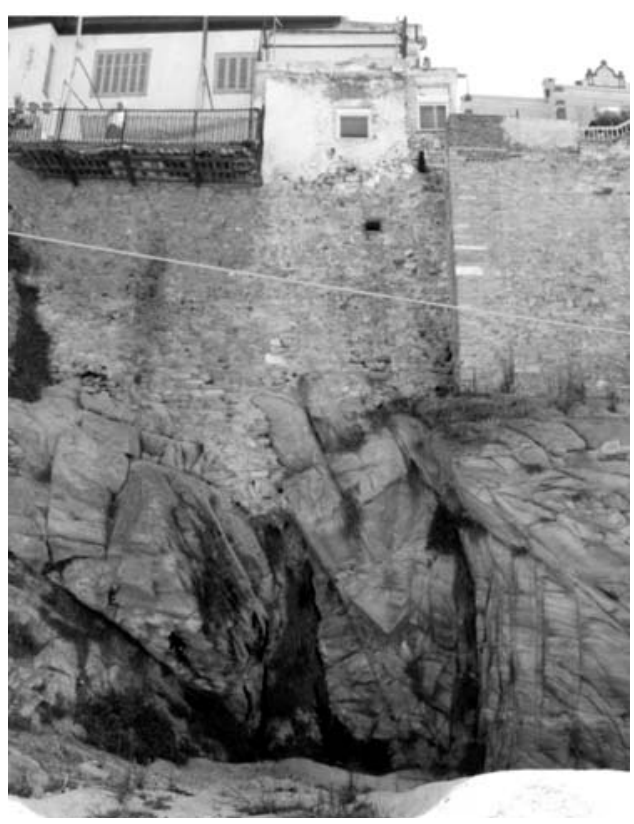

Fig. 3: Location P4. An intensively fractured zone caused by a fault. The wave erosion caused intensive underexcavation to the slope.

the wall was constructed in direct continuity with the slope. Even worse, in some places the wall was constructed forming a bridge across the two sections of the fault (Fig $3 \& 5 B, C, D)$. Figures 2 to 5 present typical examples of sections appearing slope stability problems capable of effecting the Byzantine monument.

The statistical analysis of joint sets measurements, conducted along the slopes, proved that the rock mass was intersected by 3 major joint sets: a) J1: 305/72, b) J2: 203/86 and c) J3:240/8. J1 and J2 are almost vertical, forming the slopes, while $\mathrm{J} 3$ is almost horizontal rising to the slopes. As expected, the joint sets are parallel to the main fault direction, $200 / 77 \& 283 / 81$, intersecting the peninsula (Fig. 1). Referring to the slopes, they are distributed in two main directions 272-302/65-90 and 202-216/45-85.

Stability analyses conducted for the slopes with a dip direction $272^{\circ}-302^{\circ}$, revealed that joints sets $\mathrm{J} 1$ and $\mathrm{J} 2$ form rock wedges rising along the slopes. These wedges tend to slide along the axis formed by the intersection of the before mentioned joints, with an angle of $73^{\circ}$. The slopes appearing a dip angle smaller than $73^{\circ}$ are safe, as the rock wedges are self supported. On the contrary, the slopes with a larger dip angle are unstable. These wedge slides can threat the Byzantine Wall only in cases where the foundation of the wall was constructed close to the slope edge. Precisely, in parts where the foundations were constructed in a distance smaller than half the height of the slope (Fig. 5E). Signs of oversized wedges that have already failed are visible in several parts of the slopes (Figs. 2, 4 and 6).

The corresponding analyses conducted for the slopes with a dip direction $202^{\circ}-216^{\circ}$ proved that those slopes are stable; no oversized rock wedges are formed (Fig. 5A). The only stability problems can be expected by the falls of small rock blocks sited along the slope face. 


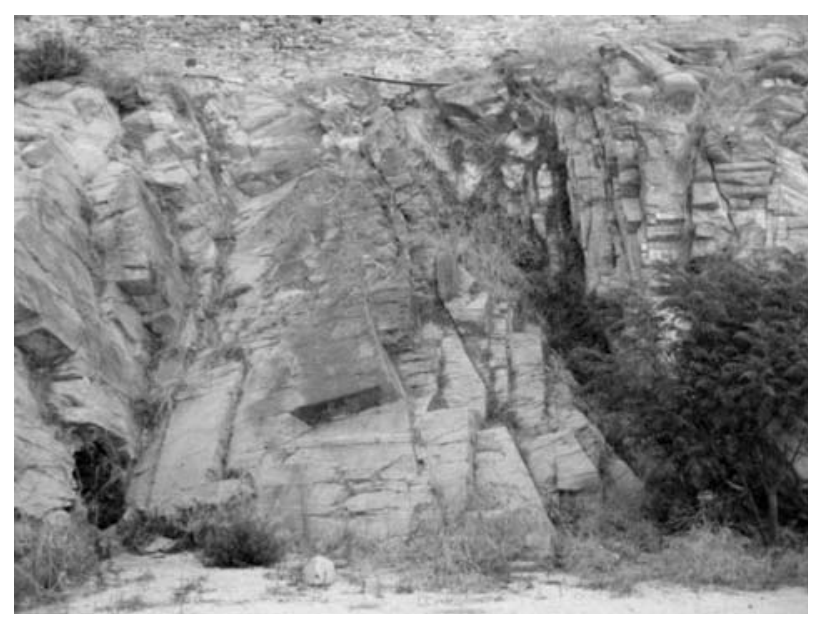

Fig. 4: Location P2. An oversized rock wedge that probably failed during the excavation of the small tunnel appearing at the base of the slope, on the left side of the picture. The extension of the failure could very easily damage the Byzantine wall.
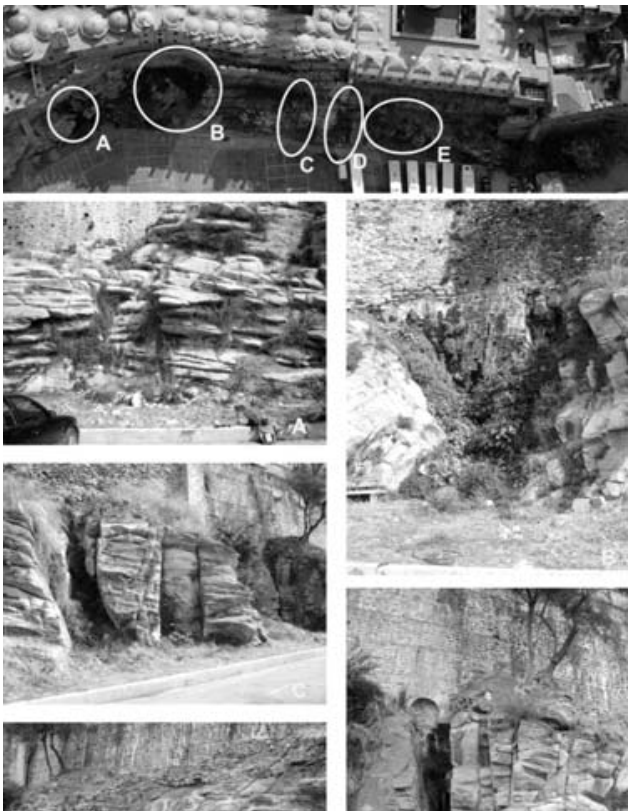

Fig. 5: Part P5. View of the slopes below Imaret monument intersected by the faults presented in the map of Fig. 1. The deterioration of the rock mass along the major tectonic lines cause serious rock slope stability problems threatening the monument. The letters pointing the various unstable locations correspond to the homonymous pictures ( $5 \mathrm{~A}$ to $5 \mathrm{E}$ ).

The South-eastern slopes present dip ranging between $45^{\circ}$ and $90^{\circ}$ and height extending 20 to $30 \mathrm{~m}$ over the sea level. The lower parts of the slopes are found into the sea, effected by the marine erosion. The longest parts of the Byzantine wall are protected from the marine erosion and from the rock wedge failures as they are founded far from the edge of the slopes. However, along parts where the slopes are intersected by numerous faults, erosion processes have formed small gulfs and the sea has approached the historical construction, putting its foundation in danger (Fig. 7).

The statistical analysis of joint sets measurements, conducted along the slopes, proved that the rock mass along the SE slopes was also intersected by the 3, before mentioned, major joint sets. Their slightly changed orientation data are: a) J1: 294/87, b) J2: 205/79 and c) J3: 112/15. Referring to the slopes, they are distributed in two main directions 102-122/75-90 and 205-216/30-55 and they are also effected by the orientation of the major tectonic structures and the joints sets. 


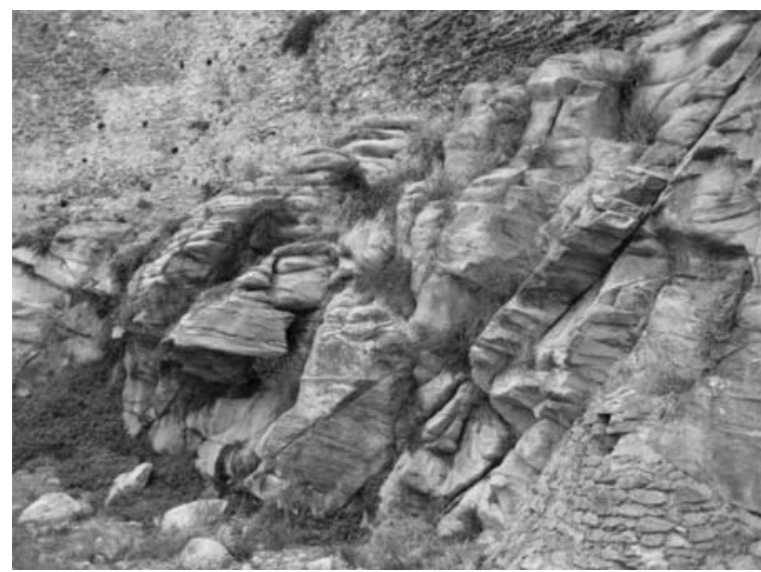

Fig. 6: Part P6. Several rock wedges are formed, to prevent them from sliding the underexcavated rock blocks were sub founded by the use of masonry walls - fills (lower right corner of the picture).
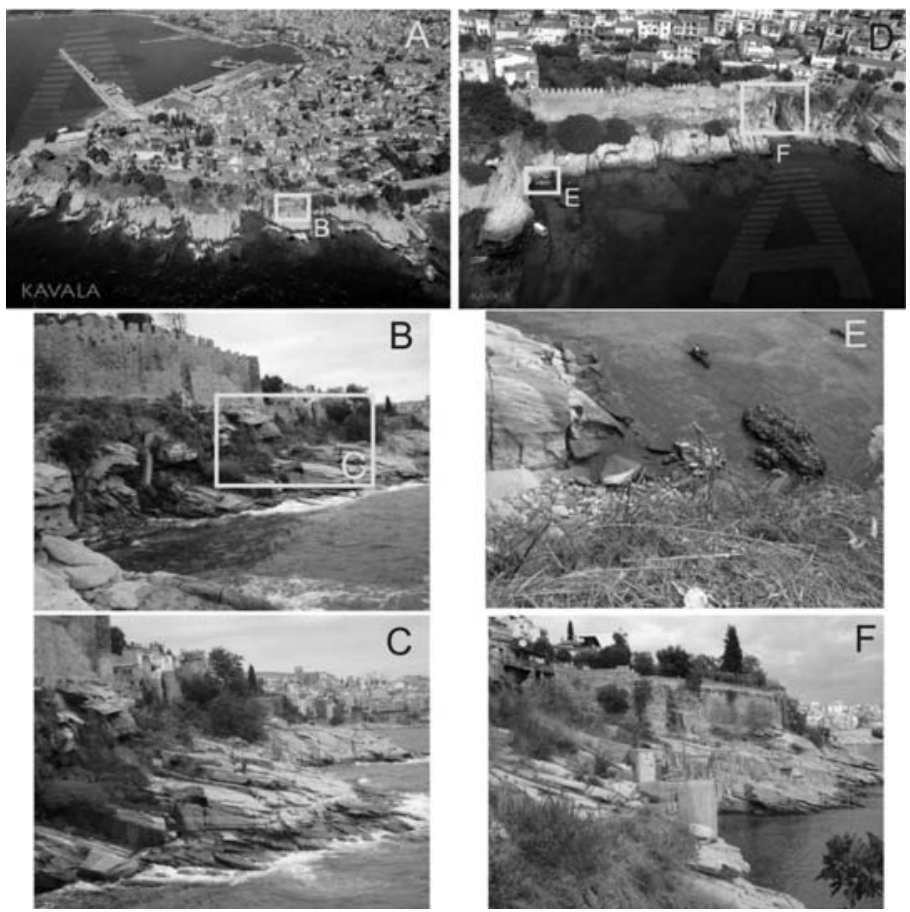

Fig. 7: Parts P9 and P10. View of the slopes along the SE part of the peninsula. Along the parts where the slopes are intersected by numerous faults the marine erosion processes have formed small gulfs and the sea has approached the historical construction, putting its foundation in danger. E: A collapsed section of the wall is presented.

Slope stability analyses applied to $205^{\circ}-216^{\circ}$ inclined slopes proved that there is no danger for rock wedges sliding. On the contrary, $\mathrm{J} 2$ combined with the other joint sets, form rock fragments prone to toppling. Therefore, the Byzantine wall's stability is in danger only at the sites where it is founded close to the slope edge. Correspondingly, slope stability analyses to the slopes presenting $102^{\circ}-122^{\circ}$ dip direction verified that there is no prospect for plain or wedge failure occurrence. However, despite $\mathrm{J} 3$ joint set's low dip angle and $\mathrm{J} 2$ perpendicular development to the slope, J1 joint set orientation appoint the slopes unstable to toppling. 


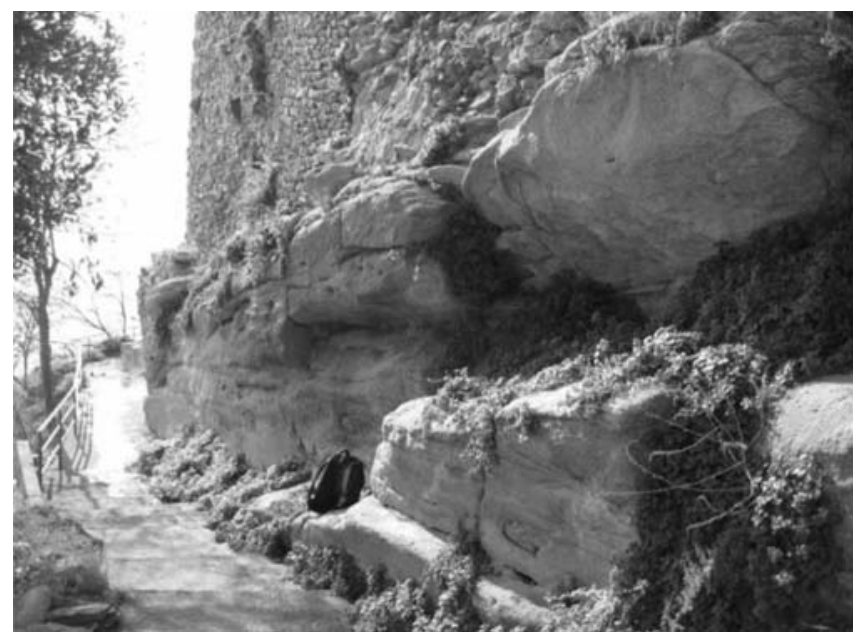

Fig. 8: Part P13. Underexcavated slope along a fault scarp. The wall was founded close to the edge. The toppling or the rupturing of the rock mass could cause extensive damages to the monument.

Concluding, the slopes sited at the SE part of Panagia peninsula are not prone to rock sliding. On the contrary, toppling is likely to occur. Rock fragments of 2-3meters maximum height could topple, especially in parts where their foot is undercut (Figs. 7, 8). These phenomena could damage the historical monument at those areas where marine erosion has excavated rupture zones reaching to Byzantine wall's foundation.

\section{Proposed support measures}

Along the slopes were located thirteen (13) parts with serious stability problems, able to effect the Byzantine wall (Fig. 1 Parts P1 to P13). These problems are a) wedge or plain failures (Varnes, 1978; Koukis \& Sabatakakis, 2007), especially along the W-SW slopes and the fault zones, b) toppling failures (Goodman \& Bray, 1976), along the SE slopes and c) extensive underexcavation problems, especially along the unprotected by the pier SE slopes. Further more, random rockfalls were recorded all around the peninsula, even along the stable parts of the slopes, because of the rock blocks sited along the slopes. Those blocks were formed by the joints intersecting the rock mass and they were displaced by the marine erosion and/or by the human activities.

The proposed support measures aim to efface the rock fall danger and to protect the Byzantine wall, by taking under consideration the monumental character of the site and the request for its minimum aesthetic destruction (Loupasakis et al., 2009).

In order to avoid the wedge, plane and toppling failures spot bolting and sub-foundation constructions were proposed. To be more precise, the overhanging blocks could be supported by grouted rock bolts installed in selected locations. The underexcavated parts could be supported by filling the void with reinforced concrete constructions (buttresses, gravity walls etc.) camouflaged by stone coating. As presented in fig. 6, sub-foundation constructions were also applied in the past.

The marine erosion of the slopes can be effaced by the installation of seawalls. These breakwater structures can be constructed by granite boulders, fitting to the surrounding bedrock and causing the minimum aesthetic distortion to the site. As presented in figure 7, the shallow sea, close to the coastline, allows the installation of the boulders by using barges. Unfortunately, these structures are going to block the small beaches formed along the gulfs. Small piers or narrow passages through the breakwater structures can provide solution to the problem. 
The random rockfalls recorded especially along W-SW slopes can be encountered by installing a safety fence or a wide hedgerow along the base of the slopes. This conventional solution does not obstruct the activities taking place along the pier because a small flowerbed has already been constructed and it only has to be upgraded.

\section{Conclusions - discussion}

This case study clearly presents that the geotechnical problems occurring at slopes used as foundation formations of castles could cause serious damages to the monuments. So, it is essential these problems to be effaced before applying any other reconstruction projects.

The modern techniques for improving the geotechnical behaviour of the geological formations and of the rock mass, in particular, can provide solutions without causing serious aesthetic distraction to the sites.

The general conclusion that, the geotechnical problems should be effaced according to priority, could be proposed to all monuments appearing geotechnical problems of all kinds (slope stability, landslides, settlement, subsidence etc.).

\section{References}

Donnelly, L. J., Culshaw, M. G., Hobbs, P. R. N., Flint, R. C., Jackson, P. D. , 2005. Engineering geological and geophysical investigations of a slope failure at Edinburgh Castle, Scotland. Bulletin of Engineering Geology and the Environment, 64: 119-137.

Ghosh, D. K., 1990. Geological evaluation of foundations of ancient monuments and stability of rockcut caves in central India. Environmental Geology, 16:15-22 .

Goodman, R.E., Bray, J.W., 1976. Toppling of rock slopes. In Proc. Specialty Conference on Rock Engineering for Foundations and Slopes, American Society of Civil Engineers, New York, Vol. 2, pp. 201- 234.

Greif, V., Sassa, K., Fukuoka, H., 2006. Failure mechanism in an extremely slow rock slide at Bitchu-Matsuyama castle site (Japan). Landslides, 3: 22-38.

I.G.M.E., 1973. Geological map of Greece, Kavala Sheet (scale 1:50.000), Athens, I.G.M.E. Publications.

Kamh, G. M. E., 2005. The impact of landslides and salt weathering on Roman structures at high latitudes - Conway Castle, Great Britain: a case study. Environmental Geology, 48: 238-254.

Kolaiti, E. and Koumantakis, J., 1991. Engineering - Geological study of St. George castle of Cephalonia (Ionian Islands, Greece). Bulletin of the International Association of Engineering Geology, No 43, Paris.

Koukis, G., Sabatakakis, N., 2007. Geology of engineering constructions. Papasotiriou Publications, Athens, pp. 575.

Loupasakis, C., Georgakopoulos A., 2009. Geotechnical problems occurred at the costal wall of Kavala, at the Lighthouse location, and the proposed protection measures. Proceedings of the $2^{\text {nd }} \mathrm{Pan}-\mathrm{Hel}-$ lenic conference of the Society for research and promotion of scientific reconstruction of monuments, pp. $189-191$.

Loupasakis C., Spanou N., Kanaris D., Exioglou D., 2009. Geotechnical investigation of the stabi-lity of rock slopes located at the Kavala municipality. Unpublished report, IGME, Athens pp. 111.

Topal, T., Akin, M, Ozden, U. A., 2007. Assessment of rockfall hazard around Afyon Castle, Turkey. Environmental Geology, 53:191-200.

Varnes, D.J., 1978. Slope movement types and processes. In Special Report 176: Landslides: Analysis and Condrol, Eds.: Schuster R.L., Krizek R.J., TRB, Natioal Research Concil, Washington D.C., pp. 12-33.

Vlcko, J., 2004. Extremely slow slope movements influencing the stability of Spis Castle, UNESCO site. Landslides, 1:67-71. 